\title{
Анализ ИК спектрограмм древесины методом моделирования формы полос поглощения
}

\author{
(с) 2021 Камалова Н.С., Саушкин В.В., Евсикова Н.Ю. \\ Воронежский государственный лесотехнический университет имени Г.Ф. Морозова, Воронеж
}

Поступила в редакцию 9.10.2020 г.

DOI: $10.17308 /$ sorpchrom.2021.21/3223

В работе рассматривается проблема разделения полос поглощения в ИК-спектрограммах такого полимерного композита, как природная древесина при анализе изменения его влажности. Использование известных программных пакетов при анализе такого композита как природная древесина не приносит необходимого эффекта, поскольку размытость пиков вызвана не высоким уровнем шумов, а многокомпонентностью и нерегулярностью составляющих.

Целью данной работы является демонстрация возможностей формализованного моделирования при разделении полос в ИК-спектрограмме природной древесины после увлажнения образцов. В качестве данных эксперимента использовались ИК-спектры микротомных срезов натуральной древесины сосны толщиной 140-150 мкм. Образцом сравнения был атмосферный воздух в измерительной камере при комнатных условиях, спектр которого определялся непосредственно перед каждым экспериментом. Исследования проводили с помощью инфракрасного Фурье-спектрометра ФСМ 2201 производства ООО «Инфраспек» (Россия, Санкт-Петербург).

Разделение полос поглощения осуществлялось методом моделирования их формы функцией нормального распределения с двумя параметрами: максимальной величиной относительной интенсивности и дисперсией. Для определения параметров использовался метод минимизации среднеквадратичного отклонения. Возможности метода в статье демонстрируются при анализе изменения относительной интенсивности двугорбой полосы в области 2360-2330 обратных сантиметров в ИК-спектрограмме древесины до и после увлажнения.

Результаты моделирования показали, что понижение интенсивности на исследуемом участке спектрограммы после увлажнения сопровождается выравниванием и снижением интенсивности этих полос. Это выравнивание и снижение косвенно указывает уменьшение количество молекул СО2 в порах древесины, а, следовательно, на увеличение в них концентрации молекул воды после выдерживания в бюксе. Этот вывод подтверждается наблюдаемым увеличением интенсивности полосы поглощения, соответствующей концентрации связной воды в порах. Таким образом моделирование полос поглощения позволяет определить количественно по изменению интенсивности полос относительное изменение концентрации молекул воды, а, следовательно, однозначно определить уровень изменения влажности древесины. Подобный метод позволяет конкретизировать механизмы влагопереноса в микропорах древесины и приводит к возможности прогнозирования получения материала с заданными гидрофобными и диэлектрическими свойствами.

Ключевые слова: инфракрасная спектроскопия, полимерные композиты, тонкая структура полос поглощения, биокомпозиты.

\section{Введение}

В настоящий момент полимерные композиты являются самыми распространенными материалами, используемыми в различных отраслях экономики практически всех стран. Этот факт - прямое следствие таких особенностей полимеров, как изменение своих свойств под влиянием внешних факторов. Такая «гиб- 
кость» сделала возможным создание материалов с заранее заданными свойствами на основе полимерных композитов, причем как химическими [1-2], так и физическими методами [3-9]. Подробно исследовалось влияние ультразвукового [3] и слабого импульсного магнитного поля на структуру высокомолекулярных соединений и полимерных композитов, в том числе и природного происхождения [4-9]. Известно, что модифицирование древесины с обработкой импульсным магнитным полем увеличивает не только плотность, но и поверхностную твердость древесины [10-11]. Использование в мебельном производстве такого материала на основе древесины, как арбоформ (жидкая древесина), позволяет существенно расширить возможности дизайна в этой области промышленности.

Естественно, что подобные изменения свойств полимеров и их длительное проявление невозможны без изменения их микроструктуры на уровне атомов и молекул. Существует немного способов достоверного исследования сложных полимерных композитов на микроуровне. Одним из наиболее эффективных способов изучения флуктуаций микроструктуры таких материалов является ИК-спектроскопия [12,13]. Проблемой широкого применения этого метода в области сложных гетероструктур, особенно природного происхождения, является наложение полос поглощения, не позволяющее адаптированно анализировать спектрограммы, а, следовательно, изучать влияние внешних факторов на их надмолекулярную структуру. При этом способы математического анализа (формальное стохастическое моделирование) таких спектров не дают уверенности в однозначности интерпретации результатов их моделей. Решение такой проблемы лежит в области формализованного моделирования, основанного на ясном вербальном (физическом) представлении о процессах, приводящих к наложению полос поглощения, причем параметры процессов должны нести ясный физический смысл.
Целью данной работы является демонстрация возможностей формализованного моделирования при разделении полос в ИК-спектрограмме природной древесины после увлажнения образцов.

Большинство программных пакетов, позволяющих автоматизировать подобные операции довольно дорогостоящи. Например, PeakFit стоит около 500 фунтов стерлингов, а другие пакеты еще дороже. К тому же основная операция для установления скрытых пиков использует гауссову функцию отклика с алгоритмом деконволюции. Основой операции деконволюции спектра является фильтрация по Винеру с дополнительными операциями (например, 2-кратное дифференцирование результата пороговой обработки [13]). Кроме того, в современных модификациях ИК-спектрометров заложена компьютерная обработка с фильтрацией, поэтому использование этих программных пакетов при анализе такого композита как природная древесина не приносит необходимого эффекта, поскольку размытость пиков вызвана не высоким уровнем шумов, а многокомпонентностью и нерегулярностью некоторых составляющих.

\section{Экспериментальная часть}

В качестве данных эксперимента использовались ИК-спектры микротомных срезов натуральной древесины сосны толщиной 140-150 мкм. Образцом сравнения был атмосферный воздух в измерительной камере при комнатных условиях, спектр которого определялся непосредственно перед каждым экспериментом. Исследования проводили с помощью инфракрасного Фурье-спектрометра ФСМ 2201 производства ООО «Инфраспек» (Россия, Санкт-Петербург). Спектр излучения формировался с помощью интерферометра Майкельсона в диапазоне длин волн от 400 до $7800 \mathrm{~cm}^{-1}$, при этом в качестве детектора использовался пироэлектрический датчик [14].

Воздушно-сухой образец древесины сосны в течение 40 суток выдерживался в 
бюксе в насыщенных парах воды. В результате чего древесина достигла предела гигроскопичности. В этом случае вода в древесине находится в адсорбированном состоянии, причем наблюдаются все механизмы адсорбции: в микропорах, на гидроксилах и капиллярная конденсация.

\section{Обсуждение результатов}

Особенный интерес вызвали результаты изменения ИК-спектрограмм до и после их увлажнения в интервале 2360$2330 \mathrm{~cm}^{-1}$ (двугорбой полосы), которую относят к области колебаний диоксида углерода $\mathrm{CO}_{2}$ [14-15]. Очевидно, что изменение интенсивности поглощения в этой полосе частот указывает на вытеснение воздуха из пор в следствии адсорбции паров воды. Однако, количественная интерпретация результатов эксперимента вызывает затруднения, поскольку осложнено неоднозначностью отнесения полос (рис.1). Для решения задачи был использован способ формализованного моделирования профиля полосы с помощью функции нормального распределения. После увлажнения ясно видна двугорбая полоса низкой интенсивности, тогда как до увлажнения на этом участке подобная полоса не просматривается. Таким образом, количественно определить снижение интенсивности полосы не представляется возможным. При этом, если основывать свои рассуждения на известном факте, что двугорбость исследуемой полосы связана с двумя группами сложных колебаний в молекуле $\mathrm{CO}_{2}$, которые различаются по своей природе и сильно зависят от взаимного расположения молекул в порах такого сложного композита природного происхождения, как древесина (минимальные размеры пор составляют несколько нанометров), то представляется возможным представить каждую группу суммой колебаний с частотами $\omega_{\mathrm{i}}=\mathrm{k}_{\mathfrak{i}} \mathrm{c} \quad\left(\mathrm{k}_{\mathfrak{i}}\right.$-волновой вектор, с-скорость света) с нормальным распределением амплитуды (амплитуды колебаний считаются абсолютно независимыми и случайными)

$$
S(t)=\sum_{i=1}^{N} A_{i} e^{j \omega_{i} t}
$$

тогда форму двугорбой полосы можно моделировать с помощью соотношения:

$$
\begin{aligned}
\frac{A(k)}{A_{\max }}= & \frac{A_{1}}{A_{\max }} \exp \left(-\frac{0.693\left(k-k_{1}\right)^{2}}{\sigma_{1}}\right)+ \\
& \frac{A_{2}}{A_{\max }} \exp \left(-\frac{0.693\left(k-k_{2}\right)^{2}}{\sigma_{2}}\right)(2)
\end{aligned}
$$

где $A_{1}, A_{2}$ - максимальная величина амплитуды в каждой полосе; $k_{1}, k_{2}-$ волновой вектор соответствующий частоте с максимальной амплитудой; $\sigma_{1}, \sigma_{2}$-дисперсия волнового вектора в каждой полосе. Соотношение (2) было выбрано как базовое для формализованной модели двугорбой полосы с параметрами ввода вывода $A_{1}, A_{2}, ; k_{1}, k_{2}$, и $\sigma_{1}, \sigma_{2}$.

Моделирование проводилось методом

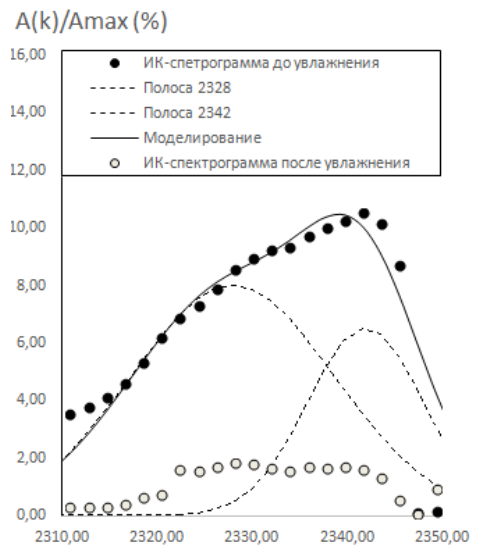

Рис.1. Результаты моделирования профиля полос и относительная интенсивность поглощения в области 2360-2330 $\mathrm{cm}^{-1}$

Fig. 1. Results of modelling the profile of the bands and the relative absorption intensity in the region of $2360-2330 \mathrm{~cm}^{-1}$ 
минимизации среднеквадратичного отклонения данных эксперимента от моделируемого профиля полосы по соотношению (2).

\section{Заключение}

Результаты моделирования показали, что до и после увлажнения образцов этот участок спектрограммы является результатом наложения двух полос 2328 и $2342 \mathrm{~cm}^{-1}$ (рис. 1). Понижение интенсивности на этом участке спектрограммы после увлажнения сопровождается выравниванием и снижением интенсивности этих полос. Это выравнивание и снижение косвенно указывает уменьшение количество молекул $\mathrm{CO}_{2}$ в порах древесины, а, следовательно, на увеличение в них концентрации молекул воды после выдерживания в бюксе. Этот вывод подтверждается наблюдаемым увеличением интенсивности полосы поглощения $1647 \mathrm{~cm}^{-1,}$ соответствующей концентрации связной воды в порах [14].

Таким образом моделирование полос поглощения позволяет определить количественно по изменению интенсивности полос относительное изменение концентрации молекул воды, а, следовательно, однозначно определить уровень изменения влажности древесины. Подобный метод позволяет конкретизировать механизмы влагопереноса в микропорах древесины и приводит к возможности прогнозирования получения материала с заданными гидрофобными и диэлектрическими свойствами.

Исследования проведены в рамках локального гранта ФГБОУ ВО «Воронежский государственный лесотехнический университет имени Г.Ф. Морозова», выделенного на проект «Разработка принципа работы цифррового устройства для измерения разности потенциалов в ксилеме стволов древесных растений».

\section{Список литературы}

1. Бельчинская Л.И., Стрельникова О.Ю., Ходосова Н.А., Ресснер Ф. //Химия, физика и технология поверхности. 2013. Т. 4. № 4. С. 420-426.

2. Бельчинская Л.И., Ходосова Н.А., Стрельникова О.Ю. и др. // Физикохимия поверхности и защита металлов. 2015. Т.51. №5. C. 1-8. DOI: 10.7868/S0044185615050046

3. Бельчинская Л.И., Жужукин К.В., Новикова Л.А., Дмитренков А.И. и др. // Лесотехнический журнал. 2019. Т. 9. № 2 (34). С. 126136.

4. Бельчинская Л.И., Жужукин К.В., Барков К.А., Ивков С.А. и др. // Конденсированные среды и межфазные границьл. 2020. Т. 22. № 1. C. 18-27.

5. Котова Д.Л., Крысанова Т.А., Новикова Л.А., Бельчинская Л.И. и др. // Сорбиионные и хроматографические прочессы. 2020. Т. 20. № 2. C. 166-174.

6. Украинцев В.Б., Мацура В.А., Потехин В.В. и др. // Журн. орг. химии. 2005. Т. 75. Вып. 8. С. 1329-1332.

7. Левин М.Н., Татаринцев А.В., Косцова О.А., Косцов А.М. // Журн. техн. физики.
2003. Т.73. Вып.10. С.85-87.

8. Кривошеев С.И., Шнеерсон Г.А., Платонов В.В. и др. // Журн. техн. физики. 2016. Т. 86. Вып. 1. С.127-131.

9. Cappelletto E., Campostrini R., Callone E., Girardi F. // J. Sol-Gel. Sci. Technol. 2012. No 62 (3). pp. 441-452. doi: 10.1007 / s10971-0122747-1.

10. Камалова Н.С., Постников В.В. Физические основы модифицирования древесины Воронеж, М-во науки и высшего образования РФ, ФГБОУ ВО «ВГЛТУ», 2019, 164 с.

11. Kamalova N.S, Postnikov V.V., Shamaev V.A., Evsikova N.Yu. // Bulletin of the Russian Academy of Sciences: Physics. 2019. Vol. 83. No 12. C. 1539-1540.

12. Lisitsyn V.I., Saushkin V.V., Kamalova N.S., Postnikov V.V. et al. // Bulletin of the Russian Academy of Sciences: Physics. 2019. Vol. 83. No 12. pp. $1543-1544$

13. Бардин Б.В. // Научное приборостроение. 2017 Т. 27. № 2. С. 75-82.

14. Жбанков Р.Г. Инфракрасные спектры целлюлозы и ее производных. Минск. 1964. $338 \mathrm{c}$.

15. Perkampus H.-H. Encyclopedia of spectroscopy: Weinheim; VCH, 1995. 787 p. 


\title{
Analysis of IR spectrograms of wood by the method of formalized modelling of the shape of absorption bands
}

\author{
(C) 2021 Kamalova N.S., Saushkin V.V., Evsikova N.Yu. \\ Voronezh State University of Forestry and Technologies named after G.F. Morozov, \\ Voronezh, Russian Federation
}

\begin{abstract}
The problem of separating absorption bands in IR spectrograms of such a polymer composite as natural wood when analysing the changes in its moisture content is considered in the study. The use of well-known software packages in the analysis of such a composite as natural wood does not bring the desired effect, since the blurring of peaks is not caused by a high level of noise, but by the multicomponent composition and irregularity of the components.

The aim of this study was the demonstration of the possibilities of formalized modelling for separating bands in the IR spectrogram of natural wood after moistening the samples. As the experimental data, we used the IR spectra of microtome sections of natural pine wood with a thickness of 140-150 $\mu \mathrm{m}$. The reference sample was atmospheric air in the measuring chamber under room conditions, the spectrum of which was determined immediately before each experiment. Research was carried out using infrared Fourier spectrometer FSM 2201 manufactured by OOO "Infraspek" (Russia, St. Petersburg).
\end{abstract}

Separation of absorption bands was carried out by modelling their shape with a normal distribution function with two parameters: the maximum value of the relative intensity and dispersion. For the determination of the parameters, the method of minimizing the standard deviation was used. The capabilities of the method are demonstrated in the article by analysing the change in the relative intensity of a double-peaked band in the range of 2360-2330 reciprocal centimetres in the IR spectrogram of wood before and after moistening.

The simulation results showed that a decrease in the intensity in the investigated part of the spectrogram after moistening was accompanied by a levelling off and a decreased intensity of these bands. This levelling and decrease indirectly indicated a decrease in the number of $\mathrm{CO}_{2}$ molecules in the pores of the wood, and, consequently, an increase in the concentration of water molecules in them after incubation in the weighing bottle. This conclusion was confirmed by the observed increase in the intensity of the absorption band corresponding to the concentration of associated water in the pores. Thus, the modelling of absorption bands allowed quantifying the relative change in the concentration of water molecules based on the change in the band intensity, and, therefore, unambiguously determine the level of change in the moisture content of wood. This method allowed specifying the mechanisms of moisture transfer in the micropores of wood and leads to the possibility of predicting the production of a material with specified hydrophobic and dielectric properties.

Keywords: infrared spectroscopy, polymer composites, fine structure of absorption bands, biocomposites.

\section{References}

1. Bel'chinskaya L.I., Strel'nikova O.Yu., Khodosova N.A., Ressner F., Khimiya, fizika $i$ tekhnologiya poverkhnosti, 2013, Vol. 4, No 4, pp. 420-426.

2. Bel'chinskaya L.I., Khodosova N.A., Strel'nikova O.Yu. et al., Fizikokhimiya poverkhnosti $i$ zashchita metallov, 2015, Vol. 51, No 5, pp. 1-8. DOI: 10.7868/S0044185615050046

3. Bel'chinskaya L.I., Zhuzhukin K.V., Novikova L.A., Dmitrenkov A.I. et al., Lesotekhnicheskij zhurnal, 2019, Vol. 9, No 2 (34), pp. 126-136.

4. Bel'chinskaya L.I., Zhuzhukin K.V., Barkov K.A., Ivkov S.A. et al., Kondensirovannye sredy i mezhfaznye granitsy, 2020, Vol 22, No 1, pp. $18-27$.
5. Kotova D.L. Krysanova T.A., Novikova L.A., Bel'chinskaya L.I. et al., Sorbtsionnye $i$ khromatograficheskie protsessy, 2020, Vol. 20, No 2, pp. 166-174.

6. Ukraincev V.B., Macura V.A., Potekhin V.V. et al., Zhurn. org. khimii, 2005, Vol. 75, Is. 8, pp. 1329-1332.

7. Levin M.N., Tatarincev A.V., Koscova O.A., Koscov A.M., Zhurn. tekhn. Fiziki, 2003, Vol. 73, Is. 10, pp. 85-87.

8. Krivosheev S.I., Shneerson G.A., Platonov V.V. et al., Zhurn. tekhn. Fiziki, 2016, Vol. 86, Is. 1, pp. 127-131.

9. Cappelletto E., Campostrini R., Callone E., Girardi F., J. Sol-Gel. Sci. Technol, 2012, No. 62 (3), pp. 441-452. doi: 10.1007 / s10971-0122747-1.

10. Kamalova N.S., Postnikov V.V. Fiziches- 
kie osnovy modificirovaniya drevesiny Voronezh, M-vo nauki i vysshego obrazovaniya RF, FGBOU VO «VGLTU», 2019, 164 p.

11. Kamalova N.S., Postnikov V.V., Shamaev V.A., Evsikova N.Yu., Bulletin of the Russian Academy of Sciences: Physics, 2019, Vol. 83, No 12, pp. 1539-1540.

12. Lisitsyn V.I., Saushkin V.V., Kamalova N.S. , Postnikov V.V. et al., Bulletin of the Russian Academy of Sciences: Physics, 2019, Vol.

Камалова Нина Сергеевна - к.ф-м.н., доцент ФГБОУ ВО «Воронежский государственный лесотехнический университет имени Г.Ф. Морозова», Россия, Воронеж

Саушкин Виктор Васильевич - к.ф-м.н., доцент ФГБОУ ВО «Воронежский государственный лесотехнический университет имени Г.Ф. Морозова», Россия, Воронеж

Евсикова Наталья Юрьевна - к.ф-м.н., доцент ФГБОУ ВО «Воронежский государственный лесотехнический университет имени Г.Ф. Морозова», Россия, Воронеж
83, No 12, pp. 1543-1544.

13. Bardin B.V., Nauchnoe priborostroenie, 2017, Vol. 27, No 2, pp. 75-82.

14. Zhbankov R.G. Infrakrasnye spektry cellyulozy i ee proizvodnykh, Minsk, 1964, 338 p.

15.Perkampus H.-H. Encyclopedia of spectroscopy: Weinheim; VCH, 1995.787p.

Kamalova Nina S. - PhD in Physics and Mathematics, Associate Professor, FSBEI HE «Voronezh State University of Forestry and Technologies named after G.F. Morozov», Russia, Voronezh

Saushkin Victor V. - PhD in Physics and Mathematics, Associate Professor, FSBEI HE «Voronezh State University of Forestry and Technologies named after G.F. Morozov», Russia, Voronezh

Evsikova Natalia Yu. - PhD in Physics and Mathematics, Associate Professor, FSBEI HE «Voronezh State University of Forestry and Technologies named after G.F. Morozov», Russia, Voronezh 